\title{
SEDIMENT TRANSPORT AND BEDLOAD LITHOLOGY IN STREAMS OF THE TETON RANGE, WYOMING
}

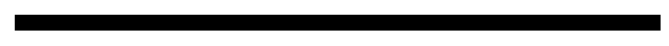

$\uparrow \quad$ ABSTRACT

The ability of streams to erode bedrock and transport sediments is controlled by discharge. Yearly snowmelt, bedrock, and nearby rockfall deposits influence the flow of water and the sediments available for transport. Discharge and bedload sediments were observed over two summers to understand the impacts of precipitation and lithology on five stream channels in the Teton Range. Discharge was higher and bedload clast sizes were larger when more snowfall fell in the preceding winter months. All streams were able to transport sand to small gravel sediments. The type of lithology observed in the bedload was mostly controlled by bedrock available throughout the entire catchment.
\end{abstract}

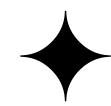

\author{
AMBER RITCHIE $\uparrow$ LISA M. TRANEL \\ ILLINOIS STATE UNIVERSITY $\uparrow$ NORMAL
}

\section{$\uparrow \quad$ INTRODUCTION}

Stream erosion plays an important role in the evolution of mountain landscapes by incising into bedrock and transporting materials from talus or glacial till deposited on valley floors (Whipple et al., 2000; Kirby and Whipple, 2001). Recent investigations show that sediments carried by streams provide tools for streambed abrasion. Maximum erosion occurs when coarse-grained sediment is transported over partially exposed bedrock. Fine-grained sediments in streams (clay, silt, and sand) abrade channel beds less effectively because they are transported by suspension (Sklar and Dietrich, 2001). Therefore, larger clasts (gravel, pebbles, cobbles, and boulders) play a more important role in stream abrasion and incision. The mean and median grain sizes, as well as sediment volume, can quantify the potential incision efficiency in mountain streams (Tomkin et al., 2003; Torizzo and Pitlick, 2004).

Efficient erosion and downstream changes in channel geometry are mostly due to increasing discharge during high flow or flood-like conditions (Leopold and Maddock, 1953). As discharge increases, streams are more likely to incise into the bedrock (Park, 1977). Mountain streams with steep, confined valleys and high colluvial input from adjacent hillslopes are likely to display different patterns of downstream channel geometry than those of lowland alluvial streams (Wohl, 1998), however these channels receive relatively little attention compared to those in more alluvial environments (Montgomery and Gran, 2001). Thirty percent of eroded sediment is transported through the length of the stream system to the mouth (Walling, 1983). Because the mineralogy or lithology of materials moved by streams can be compared to the bedrock sources to determine patterns of erosion, incision and transport in these channels can be evaluated.

The erosional efficiency of streams in the Teton Range was investigated by analyzing stream discharge, sediment sizes and clast lithology in five different watersheds. Bedload sediments were described by their size and lithology to determine how catchments vary in the materials they transport. Changes from upstream to downstream sediment transport in mountain streams were studied to provide more insight on downstream discharge and colluvial controls. The stream channels in this study were classified as mixed bedrock-alluvial channels, which are common in actively incising terrain (Howard, 1998).

\section{STUDY AREA}

The Teton Range in northwestern Wyoming runs 64 kilometers north to south and 24 kilometers east to west and is the youngest of the Rocky Mountains, dated at five million years. The geologic history of the Teton Range is marked by many events, including Cretaceous and Neogene faulting, Quaternary glaciation, 
and volcanism associated with the nearby Yellowstone hotspot (Love et al, 2003).

Uplift began with the Laramide orogeny 80 to 55 million years ago (Roberts and Burbank, 1993). Basin and Range extension formed the Teton normal fault, and Quaternary movement has averaged $1.3 \mathrm{~mm} / \mathrm{yr}$ (Pickering White et al., 2009). The western fault block is being uplifted and tilted westward. Greatest uplift is on the eastern edge and creates the asymmetrical mountain range with high peaks and steep mountain front along the eastern margin. The fault block east of the Teton Fault is subsiding, forming modern day Jackson Hole (Love et al., 1992).

Although the Teton Mountains are a young range, the rocks making up the core of the mountains are much older. Sedimentary, igneous, and metamorphic rocks can all be found in the range (Figure 1). In the catchments observed in this study, the oldest exposed rocks are Archean gneisses (Reed and Zartman, 1973) composed mostly of quartz, feldspar, biotite, and hornblende (Love et al., 2003). The backbone of the Teton Peaks is composed of Mount Owen Quartz Monzonite, which is a granitic rock containing 30-40\% quartz, equal proportions (20-35\%) of both potassiumrich and sodium/calcium-rich feldspar, $5 \%$ or less biotite and traces of muscovite (Reed and Zartman, 1973). Irregular intrusions of pegmatite contain crystals that are upwards of several centimeters to half a meter in diameter and contain the same feldspars found in the Mount Owen Quartz Monzonite plus muscovite, biotite and brown and red garnets (Love et al., 2003). The youngest Precambrian formations are black, fine to medium grained diabase dikes (Reed and Zartman, 1973; Love et al., 1992).

Sedimentary rocks aged 510 million to 90 million years are also present in several east-draining catchments (Craighead, 2006). One of the most notable sedimentary formations observed is the Gros Ventre Formation, which is subdivided into the Death Canyon Limestone, the Wolsey Shale, the Flathead Sandstone, the Gallatin Limestone, and the Park Shale units (Foster, 1947). Also included in the sedimentary stratigraphy of the Teton Range are the cliff-forming units, the Bighorn Dolomite and the Madison Limestone formations (Love et al., 2003).

The Cambrian Flathead sandstone is white, tan, brown, or maroon sandstone, with interbedded shale. The Gros Ventre formation consists of two shale members and a limestone member. The Death Canyon Limestone is blue, gray, brown or tan and the Gallatin Limestone is dark gray and mottled tan. The Bighorn
Dolomite is a light to dark gray, fine-grained dolomite (Love et al., 1992).

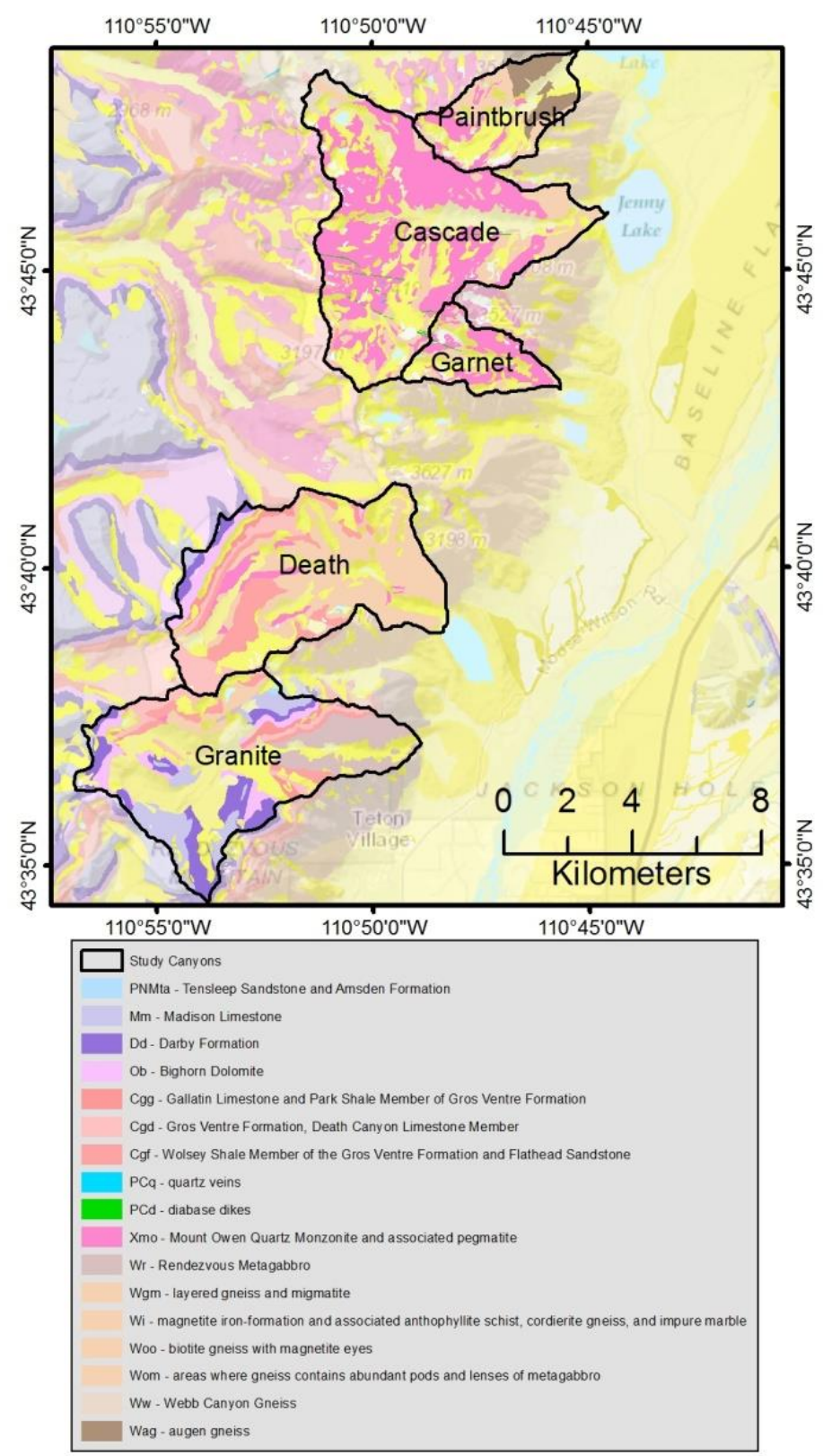

Figure 1. Geology of the Teton Range from Love et al. (1992). The geology units shown are limited to the bedrock observed in the 5 study catchments.

Glaciers in the Teton Range played an important role in shaping the landscape during two glacial episodes in the Quaternary period. The Bull Lake glaciation occurred between 160,000 to 130,000 years ago and the Pinedale glaciation began more than 30,000 years ago and lasted to 14,000 years ago. Evidence of these glacial episodes in drainage basins is preserved in moraines, U-shaped valleys, and polished rock faces. 
Alpine glacial moraine deposits left behind in the Jackson Hole valley created natural dams that formed Phelps, Jenny, and Bradley lakes (Love et al., 2003).

Although the bedrock is old and resistant, joints and fractures create some weakness in the slopes. Fractured rock faces, temperature variations and freezethaw cycles cause the rocks to crack and detach, forming talus fans on canyon floors. Streams flowing over talus deposits transport these sediments to lakes in Jackson Hole (Love et al, 2003).

Precipitation controls stream discharge and sediment transport in the Teton Range because the water source of mountain streams is primarily snow melt, rain, and melting glacial ice. Estimates of precipitation in each Teton canyon were taken from a model using the parameter elevation regressions on independent slopes model (PRISM), which predicts the precipitation expected with increasing elevation. Foster et al. (2010) applied an algorithm based on point climate measures from a network of weather stations and a digital elevation model (DEM) to create a continuous grid of precipitation using a linear climate elevation regression function. Their model showed maximum precipitation values at the topographic highs of the range, and decreased in a bulls-eye pattern away from the highest peaks. The expected relationship between mean annual precipitation from this model and the mean watershed elevation is shown in Figure 2.

\section{$\uparrow \quad$ METHODS}

Five Teton streams were studied to determine the sediment sizes that are transported and bedrock units that are most easily eroded. Field observations included stream discharge, water surface slope, clast sizes, and clast lithology. Fieldwork was completed over the summers of 2011 and 2012. Data were collected at approximately the same time of year in both field seasons, between July 25-August 13 of 2011 and July 27August 5 of 2012, to minimize error due to changes in seasonal weather. Major east-flowing drainage systems of the Teton Range were measured and included Paintbrush, Cascade, Garnet, Granite, and Death canyons. Streams were selected based on catchment area $\left(10-43 \mathrm{~km}^{2}\right)$, bedrock variability, and accessibility (Figure 3).

Channel cross-section areas, flow velocities and sediment sizes were collected at upstream and downstream locations in each watershed. The crosssection area was calculated using the Reimann sum method of integration. Flow velocity and depth were measured with an FP101 global flow probe. The area was multiplied by velocity to calculate the total discharge. The slope of the water and bed surfaces was observed with a Laser Inc. Technology Trupulse $360^{\circ} \mathrm{B}$ laser rangefinder. At each sampling location, 50 clasts were measured in the field to determine the range of sizes within the stream channel. Ten clasts were chosen at random across the channel to determine the lithology of cobbles present. Sand and finer grains were collected by scooping sediment which had accumulated in the channel. Sediment samples were cleaned, dried and sieved to $0.002 \mathrm{~mm}, 0.05 \mathrm{~mm}$, and $2 \mathrm{~mm}$ at Illinois State University. Mineral compositions of 50 randomly selected grains were observed under a microscope. A 32 ounce water sample was collected and filtered to measure suspended solids.

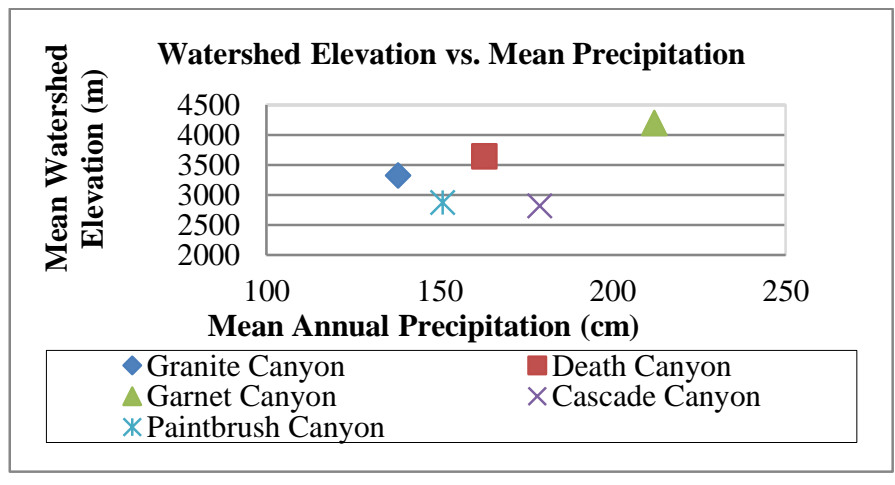

Figure 2. Mean annual watershed precipitation and mean watershed elevation created from data modeled in Foster et al. (2010).

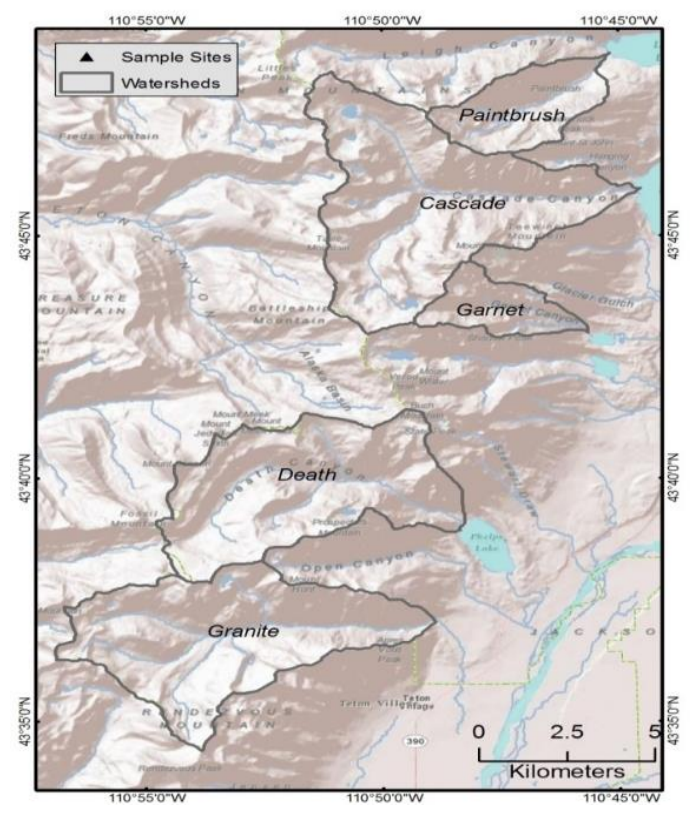

Figure 3. Watersheds studied and location of channel cross sections and sediment observations. 
The largest particle size potentially carried by each stream was calculated based on basal and critical shear stresses. The basal shear stress, $\tau_{b}$, is the force imparted on the streambed by moving water and was calculated with the equation:

$$
\tau_{\mathrm{b}}=\Upsilon_{\mathrm{w}} * \mathrm{R} * \mathrm{~S}
$$

where $\Upsilon_{w}$ is the specific weight of water $\left(9800 \mathrm{~N} / \mathrm{m}^{3}\right), R$ is the hydraulic radius of water, and S is the slope of the water surface. Critical shear stress, $\tau_{c}$, is the theoretical force required to pick up a grain of diameter (d) and was calculated by the equation:

$$
\tau_{\mathrm{c}}=\Theta_{\mathrm{ec}}\left(\Upsilon_{\mathrm{s}}-\Upsilon_{\mathrm{w}}\right) \mathrm{d}
$$

where $\Theta_{\text {ec }}$ is the Shield's parameter for turbulent flow (0.044), $\Upsilon_{s}$ is the weight density of the grain $(26,000$ $\left.\mathrm{N} / \mathrm{m}^{3}\right), \Upsilon_{\mathrm{w}}$ is the specific weight of water $\left(9800 \mathrm{~N} / \mathrm{m}^{3}\right)$, and $\mathrm{d}$ is the grain diameter $(\mathrm{m})$.

A comparison of shear stresses describes the sediment erosion and transport conditions in stream channels. If the basal shear stress were greater than the critical shear stress, then erosion, or entrainment, of the sediment grains would occur in the stream channel. If the basal shear stress were less than the critical shear stress then no erosion would occur and sediments would be deposited. The basal shear stress was set to equal the critical shear stress to solve for the maximum grain diameter carried by each stream.

A digital elevation model (DEM) and the Hydrology tools in ArcGIS 10.0 were used to define the flow network and watershed boundaries in the study catchments. A geologic map of Grand Teton National Park (Love et al., 1992) was used to calculate the area of each bedrock unit within each catchment. The stream cobble and sediment mineral compositions were compared to the mapped bedrock areas to determine the primary source of sediments.

\section{$\uparrow \quad$ RESULTS}

\section{Discharge}

Stream discharges for 2011 were 35\% higher than 2012 (Table 1). Snowfall in the preceding winter and spring was also higher in 2011 than in 2012 (Table 2). At Teton Village, 238 inches of winter snowfall was observed in 2011, while only 108 inches of snowfall was recorded in 2012 (total of monthly snowfall from October to May for both years reported on Weather Warehouse website: https://weather-warehouse.com).
Table 1. Summary of discharges measured at each channel cross section.

\begin{tabular}{|c|c|c|c|}
\hline Canyon & Location & $\begin{array}{c}\mathbf{2 0 1 1} \\
\text { Discharge } \\
\text { (m3/s) }\end{array}$ & $\begin{array}{c}\mathbf{2 0 1 2} \\
\text { Discharge } \\
\text { (m3/s) }\end{array}$ \\
\hline \hline \multirow{2}{*}{ Granite } & Upstream & - & 1.45 \\
& Downstream & - & 2.63 \\
\hline \multirow{2}{*}{ Death } & Upstream & - & - \\
& Downstream & 8.78 & 2.2 \\
\hline \multirow{2}{*}{ Garnet } & Upstream & 1.45 & 1.08 \\
& Downstream & 2.12 & 0.86 \\
\hline \multirow{2}{*}{ Cascade } & Upstream & 2.29 & 0.71 \\
& Downstream & 12.26 & 8 \\
\hline \multirow{2}{*}{ Paintbrush } & Upstream & - & 1.8 \\
& Downstream & 4.72 & 1.37 \\
\hline
\end{tabular}

In all but one stream, discharge increased downstream. Granite Canyon showed an $81 \%$ increase in discharge from upstream to downstream. Garnet Canyon showed a $26-46 \%$ increase in stream discharge from upstream. The combined discharge from the north and south forks of Cascade Canyon was $6.22 \mathrm{~m}^{3} / \mathrm{s}$ in 2011 , which increased $97 \%$ to $12.26 \mathrm{~m}^{3} / \mathrm{s}$ at the downstream location when the two forks had joined. In 2012, the combined discharge from the north and south forks of Cascade Canyon was $2.03 \mathrm{~m}^{3} / \mathrm{s}$, which increased $294 \%$ to $8.0 \mathrm{~m}^{3} / \mathrm{s}$ at the downstream location. Paintbrush Canyon had a $31 \%$ decrease in stream discharge from upstream to downstream, thus being the only stream to have a lower discharge at the downstream location.

Table 2. Summary of winter snowfall preceding summer field seasons. Snowfall values from Weather Warehouse website: https://weather-warehouse.com.

\begin{tabular}{|c|c|c|c|}
\hline \multirow{2}{*}{ Month } & \multicolumn{3}{|c|}{ Snowfall } \\
\cline { 2 - 4 } & $\mathbf{2 0 1 0}$ & $\mathbf{2 0 1 1}$ & $\mathbf{2 0 1 2}$ \\
\hline \hline January & & 45.4 & 27.8 \\
February & & 20.4 & 29.2 \\
March & & 44.4 & 10.6 \\
April & & 31.5 & 3 \\
May & & 2 & 0.5 \\
June & & 0 & 0 \\
July & & 0 & 0 \\
August & & 0 & 0 \\
September & 0 & 0 & \\
October & 7.1 & 0.2 & \\
November & 36.3 & 22.3 & \\
December & 50.8 & 14.2 & \\
\hline
\end{tabular}


Although yearly snowfall influenced stream discharge, we also recognize that the amount of snowmelt also may have varied with time of day; as temperatures warmed throughout the day, more snow melted and increased discharge. Observations were collected at the same time of the year (July 25-August 10) during this study to reduce seasonal uncertainties, however the time of day often varied.

\section{Sediment Size}

The clast sizes entrained by each stream were estimated from basal shear stress, critical shear stresses and the median, $25^{\text {th }}$ percentile (Q1), and $75^{\text {th }}$ percentile (Q3) sizes were modeled at each location (Figure 4). The maximum predicted D50 (50\% of the clasts are equal to or smaller than this value) was $128 \mathrm{~mm}$ in the north fork of Cascade Canyon. The smallest predicted D50 was 19 $\mathrm{mm}$ in upper Garnet Canyon (Table 3).

Calculated and measured clast sizes were compared to determine how well the basal and critical shear stress calculations predicted sediment sizes that could be transported. Table 3 shows the predicted D50 clast sizes compared with the actual measured values at each sampling location and percent error of each. Predicted D50 sizes were all larger than the measured D50 sizes. The difference between the lowest D50 size was only $2 \mathrm{~mm}$. Overall, at higher discharges, larger clasts (D50) were found in the streambed (Figure 5).

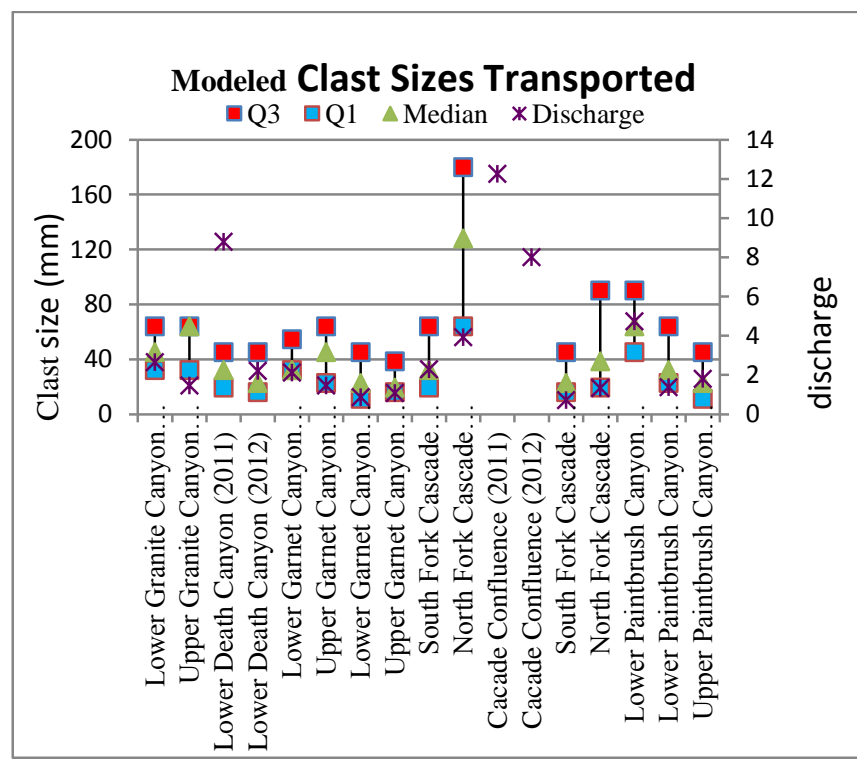

Figure 4. Stream discharge plotted with $25^{\text {th }}$ percentile (Q1: 25\% smaller), $75^{\text {th }}$ percentile (Q3: 75\% smaller) and median clast sizes.
Table 3. Predicted (Pred) and measured (Meas) D50 clast sizes for each stream cross section. D50 \% Error is the percent error between the equation-predicted and field measured clast sizes.

\begin{tabular}{|c|c|c|c|}
\hline Canyon & $\begin{array}{c}\text { Pred } \\
\text { D50 } \\
(\mathrm{mm})\end{array}$ & $\begin{array}{c}\text { Meas } \\
\text { D50 } \\
(\mathrm{mm})\end{array}$ & $\begin{array}{c}\text { D50 \% } \\
\text { Error }\end{array}$ \\
\hline \hline Lower Granite Canyon (2012) & 45 & 38 & 17 \\
Upper Granite Canyon (2012) & 64 & 49 & 27 \\
\hline Lower Death Canyon (2011) & 32 & 24 & 29 \\
Lower Death Canyon (2012) & 23 & 22 & 4 \\
\hline Lower Garnet Canyon (2011) & 32 & 31 & 3 \\
Upper Garnet Canyon (2011) & 45 & 33 & 31 \\
Lower Garnet Canyon (2012) & 23 & 20 & 14 \\
Upper Garnet Canyon (2012) & 19 & 17 & 11 \\
\hline South Fork Cascade Canyon (2011) & 32 & 26 & 21 \\
North Fork Cascade Canyon (2011) & 128 & 92 & 33 \\
South Fork Cascade Canyon (2012) & 23 & 18 & 24 \\
North Fork Cascade Canyon (2012) & 39 & 32 & 20 \\
\hline Lower Paintbrush Canyon (2011) & 64 & 26 & 84 \\
Lower Paintbrush Canyon (2012) & 32 & 26 & 21 \\
Upper Paintbrush Canyon (2012) & 23 & 18 & \\
\hline & & & 24 \\
\hline
\end{tabular}

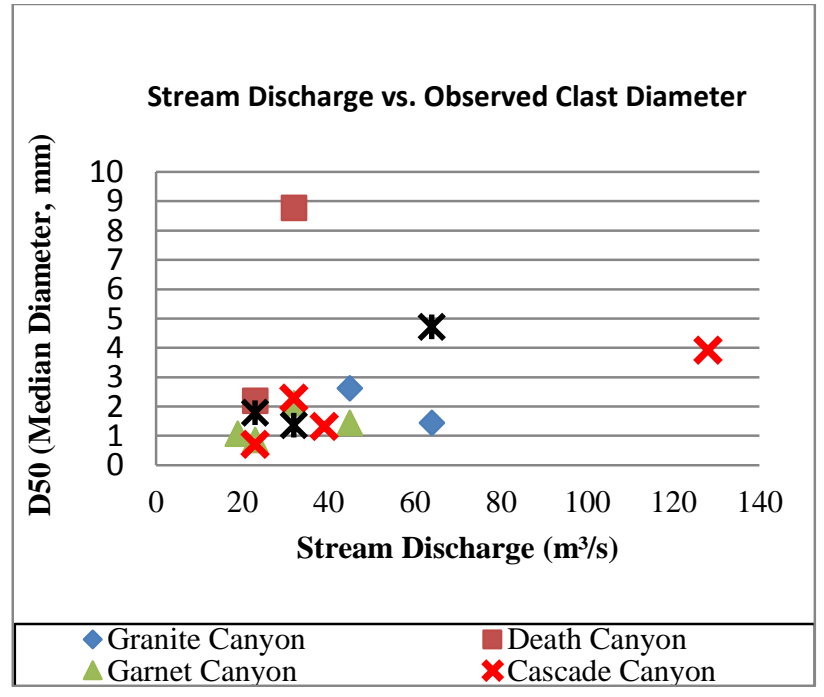

Figure 5. The relationship between stream discharge and measured clast diameters for both. 


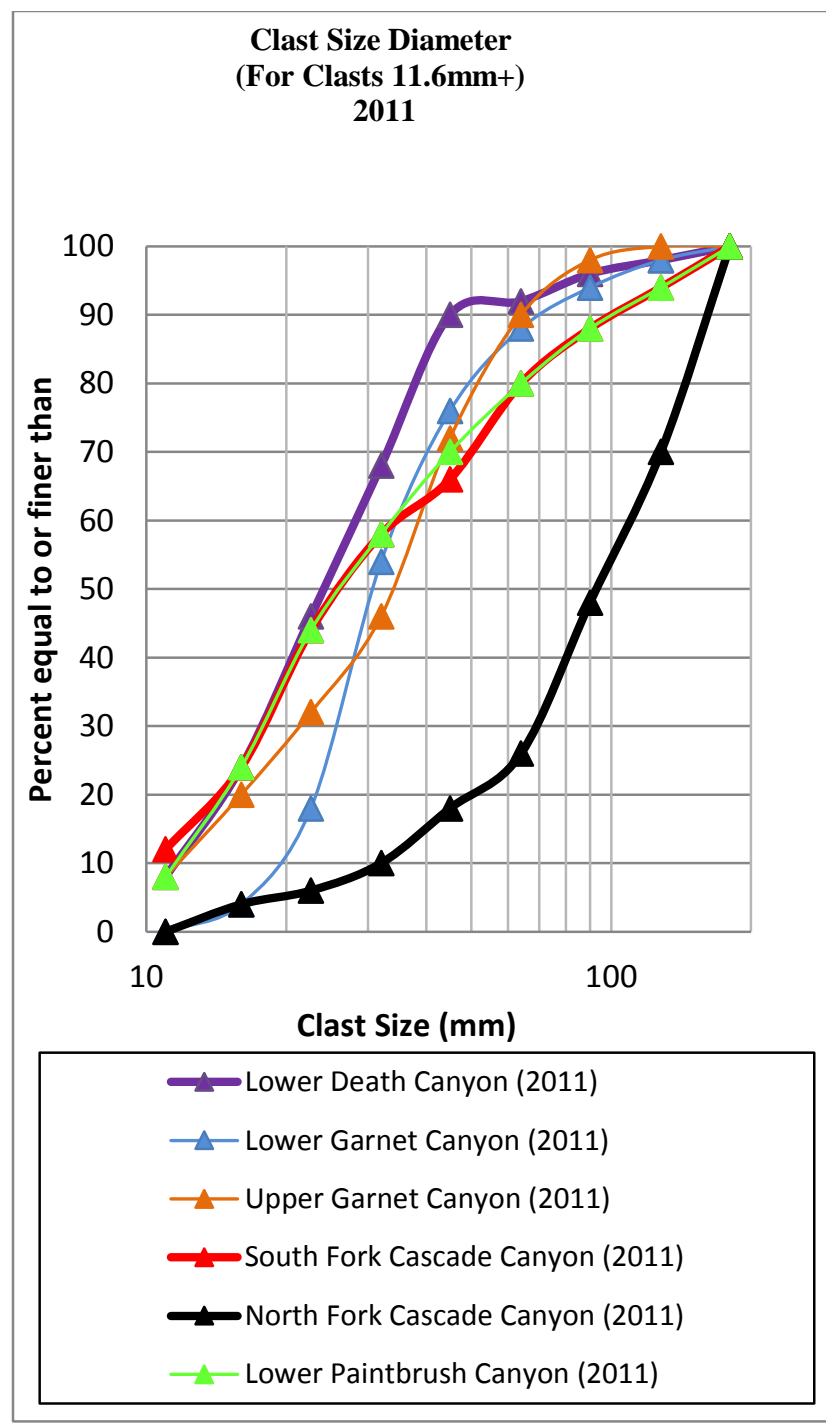

Figure 6. Cumulative sediment size curves for clasts equal to or greater than $11.6 \mathrm{~mm}$ in 2011. Bold lines represent larger watersheds.

Cumulative percent curves illustrate the bedload size distribution for clasts greater than $11.6 \mathrm{~mm}$ (Figures 6 and 7). In 2011, the north fork of Cascade Canyon had the largest clast sizes, with a measured value of $92 \mathrm{~mm}$. Watershed size did not show a strong relationship to sediment size in the 2011 observations. The summary of sediment sizes observed in cross sections in 2012 shows a stronger trend of larger watersheds containing larger bedload clasts. Both upstream and downstream sample locations in Granite Canyon (D50 of $49 \mathrm{~mm}$ for Upper Granite Canyon and D50 of $38 \mathrm{~mm}$ for Lower Granite Canyon) and the north fork of Cascade Canyon (D50 of $32 \mathrm{~mm}$ ) were the three locations with the largest clasts sampled in 2012. The stream showing the smallest clasts, Upper Garnet Canyon, had a D50 value of $17 \mathrm{~mm}$.

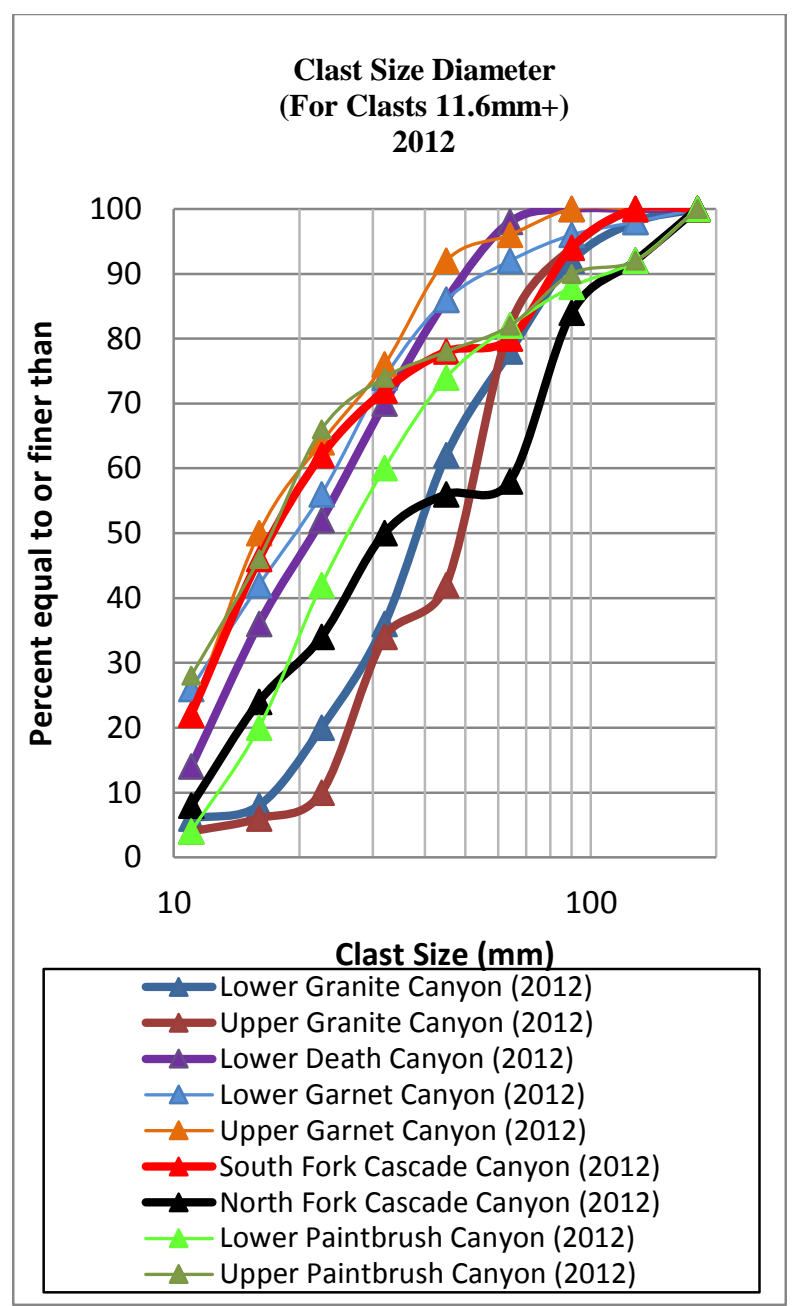

Figure 7. Cumulative sediment size curves for clasts equal to or greater than $11.6 \mathrm{~mm}$ in 2012. Bold lines represent larger watersheds.

\section{Lithology}

Primary bedrock units are comprised of granites, gneisses, and quartz monzonite with major sedimentary units in the southern end of the range (Granite and Death Canyons). In four of the five canyons that were observed, the primary bedrock composition was also the most frequently observed lithology in the active stream channel (Table 4 and Figure 8). In Paintbrush Canyon, more gneiss was mapped throughout the catchment, however, more quartz monzonite was observed in the stream. This observation may have been due to the similarities between the granitic textures in some bands of the gneissic rocks in parts of Paintbrush Canyon. Additional work will be done to look at a greater number of samples from each stream and investigate the source of minerals based on mineral properties and ages. 
Table 4. Percentages of lithology observed in stream bedload and mapped as exposed bedrock. Bedrock measurements were estimated from the geologic map by Love et al. (1992).

\begin{tabular}{|c|c|c|c|c|c|c|}
\hline \multirow[b]{2}{*}{ 己̇ } & \multirow[b]{2}{*}{ } & \multicolumn{5}{|c|}{ Lithology percentages } \\
\hline & & 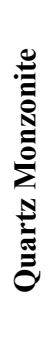 & $\frac{\mathscr{n}}{\mathscr{E}}$ & 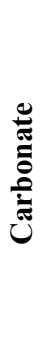 & 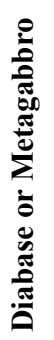 & \\
\hline Granite & $\begin{array}{l}\text { Stream } \\
\text { Bedrock }\end{array}$ & $\begin{array}{l}40 \\
<1 \\
\end{array}$ & $\begin{array}{l}0 \\
6 \\
\end{array}$ & $\begin{array}{l}60 \\
64 \\
\end{array}$ & $\begin{array}{r}0 \\
20 \\
\end{array}$ & $\begin{array}{r}0 \\
10 \\
\end{array}$ \\
\hline Death & $\begin{array}{l}\text { Stream } \\
\text { Bedrock }\end{array}$ & $\begin{array}{c}39 \\
6 \\
\end{array}$ & $\begin{array}{l}61 \\
50 \\
\end{array}$ & 28 & 0 & 16 \\
\hline Garnet & $\begin{array}{l}\text { Stream } \\
\text { Bedrock }\end{array}$ & $\begin{array}{l}77 \\
69 \\
\end{array}$ & $\begin{array}{l}23 \\
30 \\
\end{array}$ & 0 & 1 & 0 \\
\hline Cascade & $\begin{array}{l}\text { Stream } \\
\text { Bedrock }\end{array}$ & $\begin{array}{l}58 \\
71 \\
\end{array}$ & $\begin{array}{l}36 \\
26 \\
\end{array}$ & 1 & $\begin{array}{r}6 \\
<1 \\
\end{array}$ & 1 \\
\hline Paintbrush & $\begin{array}{l}\text { Stream } \\
\text { Bedrock }\end{array}$ & $\begin{array}{l}62 \\
27 \\
\end{array}$ & $\begin{array}{l}38 \\
73 \\
\end{array}$ & 0 & 0 & 0 \\
\hline
\end{tabular}

Carbonate rocks were most freqently observed in the Granite Canyon stream as was expected due to $64 \%$ of the mapped area containing limestone or dolomite. Although carbonate rocks were also mapped over a considerable area in Death Canyon (28\%), no carbonate clasts were found in the Death Canyon stream, where stream clasts were primarily composed of gneiss and quartz monzonite. In Garnet, Cascade, and Paintbrush canyons the majority of clasts were granite, quartz monzonite, and gneiss. The minerals observed in the stream sediments were primarily quartz at every location both years. As was expected, a high percentage of quartz was observed in sediment samples because quartz is present in many of the mapped bedrock units and is resistant to weathering. The suspended solids collected from the water samples showed that there were more particles in suspension in all of the canyons in 2011 than in 2012, although concentrations were low in both years.

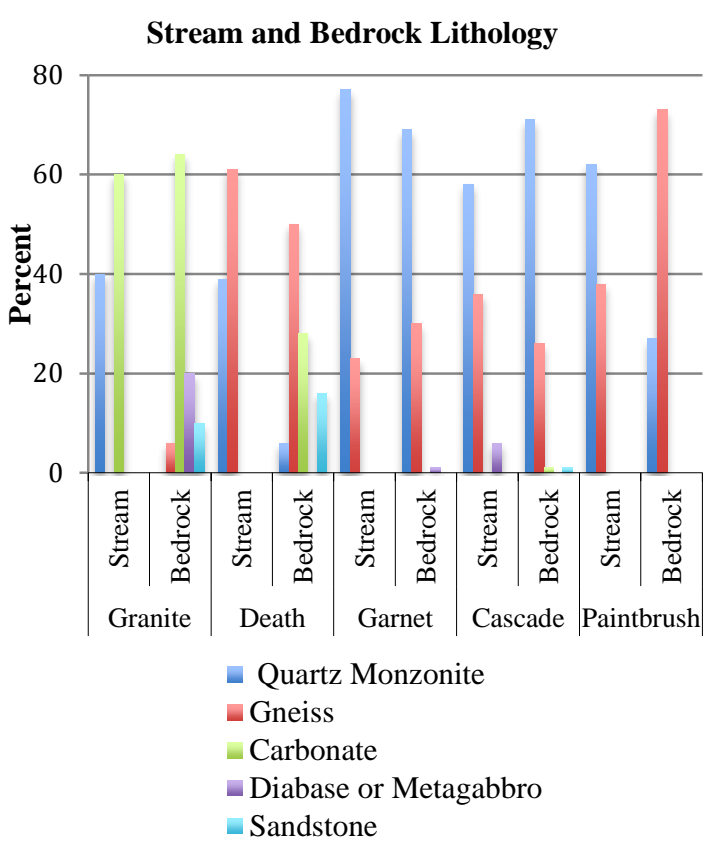

Figure 8. Distribution of lithologies observed in stream bedload and mapped bedrock units for each canyon.

\section{SUMMARY}

The study of discharge in Teton streams allowed us to evaluate how watershed area, elevation, and annual precipitation influence materials transported and eroded within stream channels. Precipitation has a direct impact on the volume of water flowing through the stream channels in Grand Teton National Park. When annual precipitation increased, the streams during late summer flow carried a higher volume of water. High snowfall over the winter months in 2011 resulted in higher July-August stream discharges as compared to 2012, when snowfall was almost half as much as the previous year and discharges were much lower.

It was hypothesized that the highest precipitation watershed would have the largest clasts moving through the stream channel. In 2011, the north fork of Cascade Canyon had the largest clasts, while in 2012, Granite Canyon had the largest clasts. Cascade Canyon had the second highest precipitation as modeled by Foster et al., 2010 while Granite Canyon had the lowest precipitation of the five canyons. This shows that the watershed with the highest elevation and precipitation did not produce the stream with the largest clasts, but that watershed area was a bigger factor in determining clast size. Overall, the consistently larger clasts observed in 2011 indicates higher discharge related to late season snowmelt enhanced the ability of streams to carry gravels. 
Although the predicted median sediment sizes are larger than the actual median sediment sizes, the values are similar. When graphically compared, a bestfit line indicates a positive correlation between actual and predicted sediment sizes (Figure 9). The error between the observed and predicted was highest in Paintbrush Canyon and the North Fork of Cascade Canyon where large boulders obstructed the stream near the cross section site. Nearby bridges may also have influenced the observed sediment sizes in Paintbrush and Death Canyon.

\section{Predicted and Observed clast sizes}

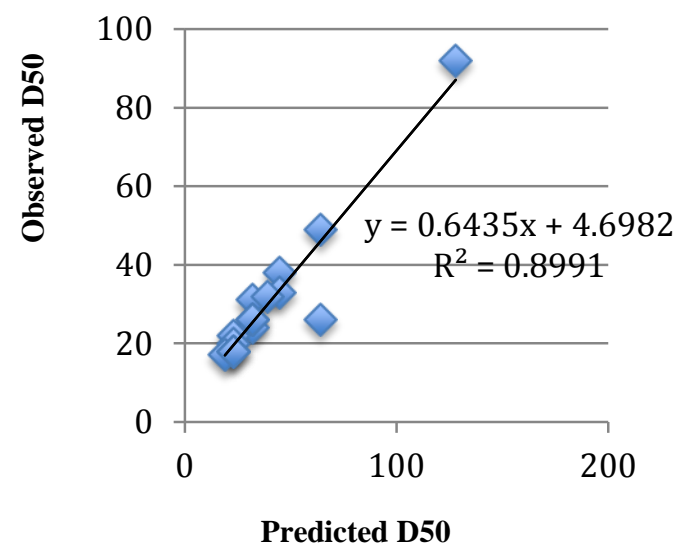

Figure 9. Clast sizes predicted from equations were compared to the clasts measured in the stream bedload. All predicted and stream observations from Table 3 are included in this graph.

In both years, the median clast sizes observed in the stream channels were pebble to cobble sized gravels. This indicates that fine debris deposited in the stream channel from rockfalls onto the valley floor can be moved throughout most of the observed catchmnets. This has important implications for studies using detrital minerals for analyses of erosion rates or patterns. Often detrital apatite, zircon, or quartz techniques require sampling sand sized sediments ranging from 63 micrometers to 2 millimeters. The results of this study indicate that the sediments of interest for detrital methods are moved, and are therefore likely to represent processes occurring throughout the entire catchment.

In most catchments, the lithology indicates a similar result related to the efficiency of the stream to transport sediments. The clasts used to observe lithology were typically cobble-sized or larger (minimum of $\sim 64$ $\mathrm{mm}$ ). The primary bedrock lithology was frequently the dominant stream bedload lithology, however there were some exceptions. The large grains observed for lithology may have been more representative of the material comprising local bedrock or nearby talus deposits. This may explain the higher concentration of quartz monzonite observed in Paintbrush Canyon and the lack of carbonate rocks in Death Canyon. The proximity of the stream to potential bedrock sources is also an important control on the distribution of carbonate rocks in Death Canyon. Many carbonate units are positioned above a ledge that does not interact with the active stream channel, therefore these rocks cannot be transported to the stream channel.

\section{ACKNOWLEDGEMENTS}

Support for this project was provided by the Illinois State University New Faculty Initiative Grant. Field assistance was provided by Audrey Happel and Meredith Frisbee (Illinois State University).

\section{$\uparrow \quad$ Literature Cited}

Craighead C. 2006. Geology of Grand Teton National Park. Moose, WY: Grand Teton Natural History Association.

Foster D, Brocklehurst SH, Gawthorpe RL. 2010. Glacial-topographic Interactions in the Teton Range. Journal of Geophysical Research Doi:10.1029/2008JF001135, 115.F01007.

Foster HL. 1947. Paleozoic and Mesozoic Stratigraphy of Northern Gros Ventre Mountains and Mount Leidy Highlands, Teton County, Wyoming. AAPG Bulletin 31: 1537-593.

Howard AD. 1998. Long Profile Development of Bedrock Channels: Interaction of Bedrock Weathering, Mass Wasting, Bed Erosion, and Sediment Transport. American Geophysical Union Geophysical Monograph 107: 297-319.

Kirby EK, Whipple KX. 2001. Quantifying differential rock-uplift rates via stream profile analysis. Geology 29:415-418.

Leopold LB, Maddock T. 1953. The Hydraulic Geometry of Stream Channels and Some Physiographic Implications. American Journal of Science 252: 606-24.

Love JD, Reed JC Jr, Christiansen AC. 1992. Geologic map of Grand Teton National Park, Teton County, Wyoming. Reston, VA: U.S. Geological Survey. 
Love JD, Reed JC Jr, Pierce KL. 2003. A Geological Chronicle of Jackson Hole and the Teton Range: Creation of the Teton Landscape. Moose, WY: Grand Teton Natural History Association.

Montgomery DR, Gran KB. 2001. Downstream Variations in the Width of Bedrock Channel. Water Resources Research 37: 1841-846.

Park CC. 1977. World-wide Variations in Hydraulic Geometry Exponents of Stream Channels: An Analysis and Some Observations. Journal of Hydrology 33: 133-46.

Pickering White BJ, Smith RB, Husen S, Farrell JM, Wong I. 2009. Seismicity and Earthquake Hazard Analysis of The Teton-Yellowstone Region, Wyoming. Journal of Volcanology and Geothermal Research: 277-296.

Reed JC Jr, Zartman RE. 1973. Geochronology of Precambrian Rocks. Geological Society of America Bulletin 84: 561-82.

Roberts SV, Burbank DW. 1993. Uplift and Thermal History of the Teton Range (northwestern Wyoming) Defined by Apatite Fission-track Dating. Earth and Planetary Science Letters. 118: 295-309.

Sklar LS, Dietrich WE. 2001. Sediment and Rock Strength Controls on River Incision into
Bedrock. The Geological Society of America. 29: 1087-090.

Tomkin JH, Brandon MT, Pazzaglia FJ, Barbour JR, Willett SD. 2003. Quantitative Testing of Bedrock Incision Models for the Clearwater River, NW Washington State. Journal of Geophysical Research 108.(B6): 2308.

Torizzo M, Pitlick J. 2004. Magnitude-frequency of Bed Load Transport in Mountain Streams in Colorado. Journal of Hydrology 290:137-51.

Walling DE. 1983. The Sediment Delivery Problem. Journal of Hydrology 65: 209-37.

Whipple KX, Hancock GS, Anderson RS. 2000. River Incision into Bedrock: Mechanisms and Relative Efficacy of Plucking, Abrasion, and Cavitation. GSA Bulletin 112: 490-503.

Weather Warehouse, 2013. Weather Source, LLC, copyright 2005-2009, Accessed April 13, 2013, https://weather-warehouse.com/

WeatherHistory/PastWeatherData_Moose_TetonVillage _WY_January.html

Wohl EE. 1998. Bedrock Channel Morphology in Relation to Erosional Processes. Geophysical Monograph 107:133-51. 